UDC: $373.2 .035: 39$

DOI: https://doi.org/10.24195/2414-4665-2017-2-13

\author{
Artur Inshakov, \\ PhD (Candidate of Philological Sciences), senior lecturer, \\ Department of Preschool Pedagogy, \\ Kryvyi Rih State Pedagogical University, \\ 54, Haharina Avenue, Kryvyi Rih, Ukraine
}

\title{
THEORETICAL BASES OF PATRIOTIC EDUCATION OF PRESCHOOL CHILDREN IN PSYCHOLOGICAL AND PEDAGOGICAL LITERATURE
}

The article deals with theoretical bases of patriotic education of preschool children. The tasks of national and cultural revival of Ukraine are the following: education of a patriotic person who is aware of his/her belonging to the Ukrainian people; of modern European civilization, who is guided by the realities and prospects of the social and cultural dynamics, which indicates the readiness for life and work in the changing world; preservation and enrichment of Ukrainian cultural and historical traditions, etc. The formation of the content of the basic elements of patriotic education of younger generation has been considered. Theoretical bases of patriotic education of preschool children have been substantiated in the paper.

Keywords: education, patriotism, civil education, personality, universal values, cultural wealth, national education.

\section{Introduction}

The relevance of the study is determined by the following tasks of the national and cultural revival of Ukraine defined in the state documents (the Law of Ukraine "On Education", the National Strategy of Development of Education in Ukraine for 2012-2021, the State National Program "Education" (Ukraine of the $21^{\text {st }}$ century): education of a patriotic person who is aware of his/her belonging to the Ukrainian people, to modern European civilization, who is guided by the realities and prospects of the social and cultural dynamics, manifests his/her readiness for living and working in the modern changing world; preservation and enrichment of Ukrainian cultural and historical traditions; the fostering of respectful attitude to national shrines and the Ukrainian language; education of a person with democratic worldview who adheres to civil rights and freedoms, respects traditions, culture, religion and the language of other nations.

Modernization of the system of preschool and secondary education, as it is defined in the National strategy of development of education in Ukraine for 2012-2021, is focused on the reflection of the national educational system in teaching and educational activity, wide use of folk pedagogy and culture, the achievements of national education.

Fostering patriotism by means of enrichment of vocabulary of ethnological contents is in close relationship with the development of speech skills.

The formation of speech skills on the ethnological basis was researched by the scholars from different positions: a role of national pedagogics in the process of formation of the personality was investigated by $\mathrm{H}$. Vashchenko, H. Volkov, O. Dukhnovych, Ya. Komenskyi, Yo. Pestalotstsi, H. Skovoroda; ethnopedagogical basis of training in native language was studied by N. Babych, A. Bohush, N. Havrysh, N. Horbunova, T. Donchenko, S. Yermolenko, S. Karaman, V. Kononenko, N. Lutsan, L. Matsko, L. Palamar, M. Pentyliuk, T. Symonenko, O. Smolinska, M. Stelmakhovych.
The issue of ethnological lexicon is presented in the works of N. Holub, R. Druzhenenko, V. Zahorodnova, L. Kozhukhovska, T. Levchenko, L. Lukianyk, H. Maksymchuk, etc. The scholars prove that a person joins the history of his/her nation, national spirituality, learns a genetic code of the nation by means of lexicon of ethnological content.

Despite a wide range of the studied issues, patriotic education of senior preschoolers by the means of ethnological lexicon remains understudied. In general, preschool children receive disparate, unsystematic knowledge of ethnology, do not use ethnological vocabulary in their speech, do not observe Ukrainian customs and traditions. In this context, there is a need for implementing various ethnolinguodidactic tools into the educational process of preschool educational institutions, relying on the achievements of ethnopedagogy, ethnopsychology, ethnosociology, ethnography, folklore studies, etc.

The article aims to consider the theoretical bases of patriotic education of preschool children in psychological and pedagogical literature.

\section{Discussion}

Under the conditions of the development of the independent Ukrainian state, the formation of national consciousness by means of socialization of a person, manifestation of his/her potential opportunities in the educational process, especially in the course of education and selfeducation becomes the defining factor. Therefore, the formation of the content of the basic elements of patriotic education of younger generation requires special attention. This can be achieved upon condition of understanding the leading educational ideal for which everyone should strive and which, in fact, causes the leading purpose of education.

The necessity of justification of the theoretical bases of patriotic education of preschool children is generally caused by the current state and the existing problems in 
social and economic, spiritual and other spheres of society functioning, the strengthening of the role of a human factor in the development of our state, the need of cardinal increase in efficiency of educational work with children on the basis of the national idea, ideals, value orientations, historical traditions of Ukrainian people. At the same time, it is necessary to find out the essence and the content of such pedagogical categories as "patriotism", "education", "educational ideal" and to consider social and psychological features of the personality development of preschool children.

Patriotism, as a unique phenomenon, is thoroughly investigated by scientists, public figures, politicians and cultural workers of Ukraine and other states. Among them it is possible to mention V. Vynnychenko, O. Dukhnovych, M. Hrushevskyi, A. Makarenko, H. Skovoroda, V. Sukhomlynskyi, K. Ushynskyi, I. Franko, T. Shevchenko, etc.

In the Ukrainian pedagogical dictionary patriotism is considered as "one of the deepest civil feelings, the content of which is love of the Motherland, devotion to its people, pride in the achievements of national culture. It is directed to all-round development of the country, the protection of its interests" [6, p. 249]. The concept "a patriot" (from Greek "patriots" - the fellow countryman, the compatriot) characterizes the person who loves his/her Motherland, is devoted to the people, ready to make a sacrifice for the sake of his/her Homeland [16, p. 720]. At the present time, different approaches to understanding the essence of patriotism have been developed by Ukrainian scientists. For example, P. Onyshchuk considers it as a feeling [11], V. Kaiukov - as one of the moral qualities of a person [8].

The most reasonable conceptual approaches were developed by M. Boryshevskyi and T. Anikina. The first researcher considers patriotism as "a value, which is embodied in selfless love to the native land, its people, the Motherland. The personality, who is a patriot, roots for the fate of his/her Motherland, experiences an effective need to devote all his/her efforts to serving compatriots, his/her own nation" [4, p. 202]. T. Anikina accurately characterized this phenomenon as "a complex integrative quality of an individual, which contains emotional and sensual, intellectual and activity components" [1, p. 7].

Interesting, in our opinion, are also views of the pedagogue N. Yemuzova who marks out several aspects of education under modern conditions: "education" as the transmitting of values; "education" as formation of the relations; "education" as creation of conditions for selfrealization of a personality. The researcher fairly notes that the person, who is being developed, cannot be considered as an object of educational influences, he/she should be considered as a subject that passes the stages of self-development, self-knowledge, self-determination, self-education, and an educator, in a broad sense of this word, should help with it [7, p. 16-17]. The author reasonably considers the concept "value" as one of the key concepts of modern social thought, which is of fundamen- tal importance in the process of studying the problems of education.

Among the Ukrainian specialists, the views of such scientists-educators are convincing: I. Bekh, who has made the psychological analysis of educational practice, has developed psychological bases of the directed formation of a personality $[2 ; 3]$. The author has proved person-centred approach in education, which, as the scientist notes, is called upon "... essential humanizing of educational process, filling it with high moral and spiritual experiences, establishing the relations of justice and respect, revealing potential opportunities of a person as much as possible, stimulating his/her personality developing creativity" [2, p. 33]; A. Kyrychuk who considers pedagogical interaction as a system-forming element of educational process, and education - as a "self-developing open system, which has the multisubjective mutually developing character", when "... in the pedagogical process not only children are developing, but also the subjects of educational influence themselves, and not only educational activity, but also the system of personal interaction, that is something bigger, than a set of separate components" $[9$, p. 3334]. The interpretation of the concept "education" contains close interrelation with national and state components. For example, M. Boryshevskyi notes that "[n]ational consciousness is an important component of civil consciousness and self-awareness of a personality". At the same time, in the formation of the latter, an important role is played by the personality's awareness of "... belonging to a certain ethnos, nation" [4, p. 189, 200].

I. Pidlasyi considers that education must take the central place in society, "... to be controlled by the state, and the main priority in the state. To give it to public, party or some other organizations means to risk statehood, independence, prosperity of the nation" [12, p. 7]. In this case, the civil education can be considered wider than the national one. With this approach, the role of national education is not decreased in any way: along with the preservation of the influence of non-state subjects, the state character of education, its compulsoriness, responsibility of the state for its organization and carrying out is actualized. At the same time, the management of the educational system, in our opinion, will be more effective. Similar approach is observed in the National program of patriotic education of the population, the formation of healthy lifestyle, strengthening of moral bases of the society, which has provided the development of the concept of civil education "... as the process of mastering the national and universal values by a personality, formation of patriotism, responsibility for destiny of the nation, the state"; in I. Bekh and Yu. Rymarenko's works [3; 13], etc.

So, in most sources, the unifying factor of civil and national education is the correlation of their purposes: the formation of a nationally conscious citizen - the patriot of Ukraine, a comprehensively and harmoniously developed personality, for whom the serving to his/her country is an internal need.

The analysis of the modern approaches of scientists shows that the phenomenon of education is considered by 
them as an extremely important social and pedagogical phenomenon, which is the defining factor of influence on the process of forming the personality of a Ukrainian citizen.

It is well known that morality is one of the most important forms of social consciousness that fills the whole process of society's activity by acting as a regulator of human behavior in all spheres of life; and value orientations are one of the most important formations in the consciousness and self-consciousness of a person that determine a number of his/her essential characteristics as an individual. According to it, the statement of the domestic scientist P. Sytnyk deserves attention, as he fairly notes that "... the underdevelopment of morality hinders civilizational progress, and its degradation inevitably leads to frustration and the death of the society" [15, p. 135].

The defining values, according to T. Mishenina, are those which reflect the essence of the national community, create such a life space that is habitual for a personality, serve as a factor of self-determination of a member of the community, who identifies him-/herself with it and is guided by the system of national values in the search for his/her own way of life or choosing the main directions of life's activity. We share the author's opinion that spirituality of a personality provides the high level of ideological conviction of a person, the formation of confidence in the importance and vital necessity of civil values, etc. [10].

The national system of education actively uses the developments of specialists in the field of patriotic education (A. Aleksiuk, I. Bekh, O. Vyshnevskyi, Ya. Hnutel, P. Kononenko, V. Maiboroda, M. Stelmakhovych), who consider fostering patriotism as the formation of a comprehensive and harmoniously developed, educated, nationally conscious person with the established civil position, patriotic feelings, cultural wealth.

Fostering patriotism is based on person's deep experiences of love and attachment to the culture, the people, the earth $[14$, p. 58]. As scientific sources testify, patriotism arises under the condition of transformation of external conditions of life and internal, deep motives of behavior and worldview into the supreme, solid personal values. Therefore it is extremely necessary for a modern pedagogue to consider present tendencies for implementation of the program of patriotic education under the conditions of formation and development of the statehood. For today, V. Sukhomlynsky's view of patriotism as "a core of a person", a basis for his/her active position, has not lost its deep meaning [17, p. 29].

Today the Ukrainian society is at the stage of continuous restructuring and radical changes, in the field of education in particular. So, in our opinion, it would be quite appropriate to build the education system, including preschool education, on the basis of a deep sense of patriotism in children, because active patriotism provides active involvement in the problems of the society, taking into account its interests, hopes, and so on. Considering this, patriotism can act as a dominant factor in combining social efforts in creation of the new Ukrainian idea.
The main objective of patriotic education, according to the researcher T. Mishenin, is the organized process of pedagogical influence on the personality of a preschool child targeted at the formation of patriotic feelings and national consciousness through a priority of national values, which provides devotion to the Homeland, readiness for self-sacrifice, respect of history of the people, their traditions, beliefs, etc. [10].

Cultural wealth as a component of the system of universal values actively influences the humanization of the society, maintains the national existence through science, literature, religion, various arts, behavior, etc., through which a child develops his/her personal experience. Therefore, universal values are interrelated with the national and cultural traditions of the Ukrainians, which is a link between the past and the future experience of the ethnos, an important component in the transformation of population into a nation and as the highest step into the universal community.

Proceeding from the foregoing, we think that on this basis an image of the ideal Ukrainian is formed. It is also noted by the researchers. In particular, H. Vashchenko, when analyzing the relationship in the formation of the nation and the ideal, noted that the nation itself is formed on the basis of traditions and the educational ideal of the Ukrainian people, and the ideal is reflected in customs, rituals, and national art. The pedagogue, while revealing a significant role in revival of national traditions, an educational ideal of the Ukrainian ethnos, its folk art, art and literature, emphasized that "as the traditional ideal it is necessary to recognize the one that has learned lessons of history, mostly corresponds to psychology of the people, has entered mentality of the masses of people, is reflected in folk art and in works of the best artists and writers who have become spiritual guides of the people" [5, p. 104].

Cultural wealth can be classified according to the approach offered by M. Boryshevskyi: 1) moral values (kindness, justice, tolerance, sincerity, mutual respect, self-esteem, responsibility, fidelity to principles and active opposition, irreconcilable relation to the opposite phenomena; mutual aid and mutual assistance); 2) civil values (patriotism, worries for destiny of the Homeland); 3 ) intellectual values (ability to think critically and self-critically, ability to have one's own objective estimates, views of various life phenomena, of a person him-/herself, sense of his/her life - as the guarantee of ability for an independent choice); 4) esthetic values (development of esthetic tastes, ability to differentiate the true noble beauty from cheap imitations, platitudes, sense of beauty); 5) ecological values (deep awareness of invaluable significance of the environment in activity of any person and society in general, careful attitude to the nature, the developed need to protect it from unreasonable and dangerous influences) [4; 14]

\section{Conclusions}

Thus, it is necessary to provide patriotic education and training of preschool age children on the basis of ethnography with the introduction of group work within preschool institutions. First of all, it is connected with the 
fact that starting from the first years of life the intimate, deep relationship between a child and everything that surrounds him/her (a lullaby, a fairy tale, a home, maternal language - all that later will become native, necessary, valuable for him/her) is established.

Patriotism is a difficult integrative personal quality peculiar to Ukrainian citizens, emotional and sensual and intellectual components of which provide: love of Ukraine; respect of national history, national and historical traditions,

\section{ЛІТЕРАТУРА}

1. Анікіна Т. О. Патріотичне виховання майбутніх учителів музики засобами художнього краєзнавства: автореф. дис. ... канд. пед. наук: 13.00.01 / Т. О. Анікіна ; АПН України. Інститут педагогіки. Київ, 1993. - 16 с.

2. Бех І. Д. Особистісно зорієнтоване виховання: науково-метод. посіб. / І. Д. Бех. - Київ : ІЗМН, 1998. $-204 \mathrm{c}$.

3. Бех І. Д. Психолого-педагогічні умови формування у молоді громадянськості / І. Д. Бех // Громадянське виховання студентської молоді в умовах трансформації суспільства: [зб. наук. ст.] : за матеріалами Всеукр. наук.-практ. семінару / М. П. Лукашевич та ін. (ред.). - Черкаси, 1998. - С. 23-27.

4. Боришевський М. Й. Національна самосвідомість особистості: сутність та шляхи становлення / М. Й. Боришевський // Система виховання національної самосвідомості учнів загальноосвітньої школи. - Київ : Райдуга, 1999. - С. 189-219.

5. Ващенко Г. Г. Виховний ідеал : підручник / Григорій Григорович Ващенко. - Торонто, 1976. - 208 с.

6. Гончаренко С. У. Український педагогічний словник / Семен Устимович Гончаренко. - Київ : Либідь, 1997. - 376 с.

7. Емузова Н. Г. Современные подходы к проблеме воспитания / Н. Г. Емузова // Актуальные проблемы воспитания личности в современных условиях: [сборник научных докладов и сообщений республиканской научно-практ. конф.]. - Нальчик: Изд-во Кабардино-Балкарского ун-та, 2000. - С. 15-22.

8. Каюков В. І. Патріотичне виховання учнів загальноосвітньої школи на героїчних традиціях українського народу: автореф. дис. ... канд. пед. наук: 13.00.01/ В. І. Каюков. - Івано-Франківськ, 1998. - 17 с.

\section{REFERENCES}

1. Anikina, T. (1993). Patriotychne vykhovannia maibutnikh uchyteliv muzyky zasobamy khudozhnoho kraieznavstva [Patriotic education of future music teachers by means of art local lore]. Extended abstract of candidate's thesis. Kyiv: APN Ukrainy. Instytut pedahohiky [in Ukrainian].

2. Bekh, I. (1998). Osobystisno zoriientovane vykhovannia: naukovo-metod. posib. [Personally oriented education: scientific and methodical manual]. Kyiv: IZMN [in Ukrainian].

3. Bekh, I. (1998). Psykholoho-pedahohichni umovy customs, and shrines of the Ukrainian people, place of birth and permanent place of living; personality's purposeful mastering of patriotic knowledge as bases of his/her patriotic educatedness; values of the Ukrainian people, their best national and historical traditions, customs, etc.; activity of patriots - outstanding members of the Ukrainian people. The reviewed psychological and pedagogical literature has shown a wide range of researchers' approaches to the issue of patriotic education.

9. Киричук О. В. Концепція виховання підростаючих поколінь суверенної України / О. В. Киричук // Радянська школа. - 1991. - № 5. - С. 33-40.

10. Мішеніна Т. М. Концепція виховного ідеалу в літературному i мистецтвознавчому краєзнавстві Криворіжжя [Електронний ресурс] / Т. М. Мішеніна. Режим доступу : http://vuzlib.com/content/view/377/.

11. Онищук П. В. Педагогічні засади технології формування патріотичних рис у учнів шкіл, гімназій, ліцеїв: автореф. дис. ... канд. пед. наук: 13.00.01 / П. В. Онищук. - Луцьк, 1996. - 22 с.

12. Підласий I. Реалії сучасного українського виховання / І. Підласий // Рідна школа. - 1999. - № 12. C. 3-12.

13. Римаренко Ю. І. Національний розвій України: проблеми і перспективи / Ю. І. Римаренко. Київ : Юрінком, 1998. - 272 с.

14. Розвиток громадянської спрямованості: [монографія] / М. Й. Боришевський, Т. М. Яблонська, В. В. Антоненко та ін. / за заг. ред. М. Й. Боришевського. - Київ, 2007. - 186 с.

15. Ситник П. К. Моральні засади трансформаційних процесів в Україні / П. К. Ситник // Стратегія розвитку України : теорія і практика / за ред. О. С. Власюка. - Київ : НІСД, 2002. - С. 134-146.

16. Словник іншомовних слів: 23000 слів та термінологічних сполучень / Уклад. Л. О. Пустовіт та ін. - Київ : Довіра, 2000. - 1018 с.

17. Сухомлинський В. О. Вибрані твори: в 5-ти т. / Василь Олександрович Сухомлинський. - Т. 3 : Серце віддаю дітям. - Київ : Радянська школа, 1977. $670 \mathrm{c}$.

formuvannia u molodi hromadianskosti [Psychological and pedagogical conditions of formation of civil consciousness among young people]. Hromadianske vykhovannia studentskoi molodi $v$ umovakh transformatsii suspilstva: zb. nauk. st. - Civil education of students in conditions of society transformation: collection of scientific articles. Cherkasy [in Ukrainian].

4. Boryshevskyi, M. (1999). Natsionalna samosvidomist osobystosti: sutnist ta shliakhy stanovlennia [National consciousness of a personality: the essence and the ways of formation]. Systema vykhovannia natsionalnoi 
samosvidomosti uchniv zahalnoosvitnoi shkoly - System of education of national consciousness of pupils of a comprehensive school. Kyiv: Raiduha [in Ukrainian].

5. Vashchenko, H. (1976). Vykhovnyi ideal: Pidruchnyk [Educational ideal: Classbook]. Toronto [in Ukrainian].

6. Honcharenko, S. (1997). Ukrainskyi pedahohichnyi slovnyk [Ukrainian Pedagogical Dictionary]. Kyiv: Lybid [in Ukrainian].

7. Yemuzova, N. (2000). Sovremennyye podkhody k probleme vospitaniya [Modern approaches to the problem of education]. Aktualnye problemy vospitaniya lichnostiv sovremennyh usloviyah: [sbornik nauchnyh dokladov $i$ soobscheniy respublikanskoy nauchno-prakt. konf.] Actual problems of personality education in modern conditions: [collection of scientific reports and reports of the republican scientific and practical conference]. Nalchik: Izd-vo Kabardino-Balkarskogo universiteta [in Russian].

8. Kaiukov, V. (1998). Patriotychne vykhovannia uchniv zahalnoosvitnoi shkoly na heroichnykh tradytsiiakh ukrainskoho narodu [Patriotic education of pupils of comprehensive school on heroic traditions of the Ukrainian people]. Extended abstract of candidate's thesis. Ivano-Frankivsk [in Ukrainian].

9. Kyrychuk, O. (1991). Kontseptsiia vykhovannia pidrostaiuchykh pokolin suverennoi Ukrainy [The concept of education of future generations of sovereign Ukraine]. Kyiv: Radianska shkola [in Ukrainian].

10. Mishenina, M. Kontseptsiia vykhovnoho idealu v literaturnomu i mystetstvoznavchomu kraieznavstvi Kryvorizhzhia [The concept of an educational ideal in the literary and art history of Kryvyi Rih]. Retrieved from: http://vuzlib.com/content/view/377/ [in Ukrainian].

11. Onyshchuk, P. (1996). Pedahohichni zasady tekhnolohii formuvannia patriotychnykh rys u uchniv shkil, himnazii, litseiv [Pedagogical bases of technology of formation of patriotic features among pupils of schools, grammar schools, lyceums]. Extended abstract of candidate's thesis. Lutsk [in Ukrainian].

12. Pidlasyi, I. (1999). Realii suchasnoho ukrainskoho vykhovannia [The realities of modern Ukrainian education]. Kyiv: Ridna shkola [in Ukrainian].

13. Rymarenko, Yu. (1998). Natsionalnyi rozvii Ukrainy: problemy $i$ perspektyvy [National scatter of Ukraine: Problems and Prospects]. Kyiv: Yurinkom [in Ukrainian].

14. Boryshevskyi, M. (Eds). (2007). Rozvytok hromadianskoi spriamovanosti [Civil orientation]. Kyiv [in Ukrainian].

15. Sytnyk, P. (2002). Moralni zasady transformatsiinykh protsesiv v Ukraini [Moral principles of transformation processes in Ukraine]. Stratehiia rozvytku Ukrainy : teoriia $i$ praktyka - The development strategy of Ukraine: Theory and Practice. Kyiv: NISD [in Ukrainian].

16. Pustovit, L. (2000). Slovnyk inshomovnykh sliv: 23000 sliv ta terminolohichnykh spoluchen [Dictionary of foreign words: 23000 words and term combinations]. Kyiv: Dovira [in Ukrainian].

17. Sukhomlynskyi, V. (1977). Vybrani tvory: v 5-ty t. T. 3: Sertse viddaiu ditiam [Selected works: in 5 volumes. Volume 3: I give my heart to children]. Kyiv: Radianska shkola [in Ukrainian].

Артур Свгенович Іншаков, кандидат філологічних наук, старший викладач кафедри дошкільної освіти, Криворізький державний педагогічний університет, просп. Гагаріна, 54, м. Кривий Ріг, Украӥна

\section{ТЕОРЕТИЧНІ ОСНОВИ ПАТРІОТИЧНОГО ВИХОВАННЯ ДІТЕЙ ДОШКІЛЬНОГО ВІКУ У ПСИХОЛОГО-ПЕДАГОГІЧНІЙ ЛІТЕРАТУРІ}

В умовах побудови незалежної української держави серед визначальних чинників формування національної свідомості вимагає уваги патріотичне виховання підростаючого покоління, зокрема дошкільнят. Актуальність дослідження обумовлена виділеними в державних документах завданнями національно-культурного відродження України. Серед них: виховання особистості-патріота, який усвідомлює свою причетність до українського народу, сучасної європейської цивілізації, орієнтується в реаліях і перспективах соціокультурної динаміки, що свідчить про готовність до життя і праці в світі, що змінюється, збереженні та збагаченні українських культурно-історичних традицій, виховання шанобливого ставлення до національних святинь, української мови; вихованні в людини демократичного світогляду, дотримання громадянських прав і свобод, шанобливого ставлення до традицій, культури, віросповідання, мови спілкування народів світу. Незважаючи на широкий спектр досліджуваних питань, проблема патріотичного виховання дошкільнят залишається відкритою. Мета нашої статті - аналіз теоретичних основ патріотичного виховання дітей дошкільного віку в психолого-педагогічній літературі. Реформування української держави стає визначальним чинником формування національної свідомості за допомогою соціологізації особистості, виявлення ії потенційних можливостей в навчально-виховному процесі, а особливо при вихованні і самовихованні. Тому вимагає уваги формування змісту базових елементів патріотичного виховання підростаючого покоління. Необхідність обгрунтування теоретичних основ патріотичного виховання дошкільнят взагалі обумовлена сучасним станом і існуючими проблемами в соціально-економічній, духовній та інших сферах функціонування нашого суспільства, посиленням ролі людського чинника в розвитку нашої держави, необхідністю кардинального підвищення ефективності виховної роботи з дітьми на основі національної ідеї, ідеалів, ціннісних орієнтацій, історичних традицій українського народу. 
При цьому необхідно визначити сутність і зміст таких педагогічних категорій, як «патріотизм», «виховання», «виховний ідеал», враховувати соціально-психологічні особливості розвитку особистості дітей дошкільного віку. Патріотизм є складною інтегративною складовою особистості українського громадянина, що передбачає любов до України, повагу до вітчизняної історії, національно-історичних традицій, святинь українського народу, місця свого народження та постійного місця проживання; цілеспрямоване оволодіння особистістю патріотичними знаннями як основи іiі патріотичного виховання.

Ключові слова: виховання, патріотизм, громадянське виховання, особистість, загальнолюдські цінності, духовні цінності, національне виховання.

Submitted on February, 20, 2017

Reviewed by Doctor of Pedagogy O. Kovshar

UDC: $37.013 .42: 159.922 .76-056.49$

DOI: https://doi.org/10.24195/2414-4665-2017-2-14

\author{
Svitlana Hryshchenko, \\ Doctor of Pedagogy, associate professor, \\ Department of Social Work, \\ Chernihiv National Pedagogical University named after T. H. Shevchenko, \\ 53, Hetmana Polubotka Str., Chernihiv, Ukraine
}

\title{
SPECIFICS OF FUTURE TEACHERS' WORK ON RE-EDUCATING DIFFICULT PUPILS OF SECONDARY SCHOOLS
}

The article focuses on the essence of future teachers' practical activity when working with difficult pupils at secondary schools. Based on certain scientific approaches, methods and techniques, the content of teaching instructions worked out in view of the specifics of educating difficult children is outlined. Suggested teaching instructions are based on the principles of re-education, personality correction, regular monitoring of the behavior norms acquisition, objective tools of influencing, teacher's control of his/her own attitude to pupils, individualization. The objectives of each component are presented in the article in details. The paper includes a list of methods and techniques according to the specifics of future teachers' work with difficult pupils and the overall results of their implementation in the school work.

Keywords: educating difficulty, difficult pupils, re-education, teachers, work specifics.

\section{Introduction}

In the twenty-first century, in the times of economic instability, changes of the fundamental moral, spiritual values and beliefs in the work of secondary school teachers of Ukraine are observed. Ukrainian scholars argue that pupils often perceive and acquire negative trends of behavior.

Educating difficulty, pedagogical neglect of children has become nowadays commonplace. Therefore, correction of these phenomena, re-education of juvenile delinquents is a key objective of secondary schools teachers.

It is essential for teachers to know the reasons of pupils' educating difficulty, to be able to influence on the child, to carry out preventive or correctional work, which could help decrease the number of delinquency caused by pupils' aggressiveness and emotional disturbance.

The problem of juvenile behavior deviations attracts attention of the scholars who thoroughly study its nature (A. Kapska, V. Orzhekhovska, L. Pidlypna, M. Sturova, O. Shestopalova, O. Shynkarenko, H. Fedoryshyn et al.). Important aspects of school adaptation of difficult children were studied by O. Hlavnyk, S. Maksymenko, K. Maksymenko. The article aims to reveal the practical aspects of teachers' educational work with difficult children. The tasks are as follows: to study the specifics of educational work with difficult children; to analyze instructions on teaching techniques concerning teachers' work on reeducation of difficult pupils of secondary schools.

\section{Methodology}

At the theoretical level, we employed the following methods: systematic analysis of educational literature on the problems of educating difficulties; logical analysis when studying theoretical background of the issue; theoretical modeling, aimed to develop instructions on teaching techniques concerning teacher's activity when re-educating difficult pupils; the empirical one - diagnostic (surveys, questionnaires) to study readiness of future teachers of various disciplines to work with difficult pupils of secondary schools; classroom observation; praximetrics: study of curricula, norms, national standards and programs; pedagogical experiment (summative and formative stages); methods of mathematical statistics. We carried out a survey of master students of three universities in the 2015-2016 academic years aimed to find out methods, techniques, components of re-educating difficult pupils of secondary schools. The scope of the study involved 124 students. The study included the summative stage (control group 